\title{
Life History of the Red Spiny Lobster, Panulirus penicillatus (Decapoda: Palinuridae), in the Galápagos Marine Reserve, Ecuador ${ }^{1}$
}

\author{
Alex Hearn ${ }^{2,3}$ and Juan Carlos Murillo ${ }^{2}$
}

\begin{abstract}
The red spiny lobster, Panulirus penicillatus (Olivier, 1791), is exploited commercially in the Galápagos Marine Reserve by the local fishing sector. Catches and catch per unit effort have declined over the past few years, leading to concerns about sustainability of the fishery. This study supports the processes regarding the fishery management of $P$. penicillatus by determining its distribution and growth parameters. Nearly 3,000 lobsters were tagged during surveys carried out at 13 islands between 2000 and 2004. Sex ratio did not differ significantly from $1: 1$, and tagging returns showed little or no movement of individuals. Mean values with $95 \%$ confidence intervals for von Bertalanffy growth parameters were estimated to be $K=0.201 \pm 0.004, \mathrm{~L}_{\infty}=16.91 \pm 0.183(\mathrm{~cm}$ carapace length), and $\Phi^{\prime}=4.14 \pm 0.019$ for males; and $K=0.264 \pm 0.02$, $\mathrm{L}_{\infty}=12.34 \pm 0.40$ (cm carapace length), and $\Phi^{\prime}=4.99 \pm 0.06$ for females. Natural mortality was 0.342 for males and 0.378 for females. These results, together with comparative estimates for red spiny lobster elsewhere, illustrate the geographical variability of growth among populations of $P$. penicillatus, which may occur within the archipelago itself.
\end{abstract}

The Red SPINy lobster, Panulirus penicillatus (Olivier, 1791), is the most widely distributed of the spiny lobsters, ranging throughout the Indo-Pacific, Red Sea, and eastern tropical Pacific islands including the Galápagos ar-

\footnotetext{
${ }^{1}$ The work described in this paper was funded through the U.S. Agency for International Development, the Government of Ecuador through a loan from the Inter-American Development Bank, and the World Wildlife Foundation. Support was also provided by the Pew Charitable Trusts Marine Conservation Fellowship program and the Pew Collaborative Initiative Fund Award. The preparation of this paper was carried out as a contribution to Work Package 7, "Simple Indicators for Sustainable Fisheries" of the INCOFISH Project (Integrating Demands on Coastal Zones with Emphasis on Aquatic Ecosystems and Fisheries), Contract INCO 003739. This document is contribution no. 1060 of the Charles Darwin Foundation. Manuscript accepted 18 June 2007.

2 Department of Marine Research and Conservation, Charles Darwin Foundation, Galápagos, Ecuador.

${ }^{3}$ Corresponding author: phone: +593 2526 146/7 ext. 123; fax: ext. 102; e-mail: ahearn@fcdarwin.org.ec.
}

Pacific Science (2008), vol. 62, no. 2:191-204

(C) 2008 by University of Hawai'i Press

All rights reserved chipelago (Holthuis 1991), where it is found around most islands and islets, inhabiting the shallow rocky subtidal zone (Hickman and Zimmerman 2000). This species is gregarious and may often be found in groups of more than 20 individuals of different sizes, in submerged caves and lava tunnels. Individuals inhabit these group shelters during the day and leave them to forage at night (Barr 1968, George 1972). Panulirus penicillatus feeds on small benthic invertebrates such as crabs, gastropods, and sea urchins (Barr 1968).

In the Galápagos, the commercial importance of $P$. penicillatus dates back to the early 1960s, and, until the advent of the fishery for the sea cucumber Isostichopus fuscus in the early 1990s, was the most lucrative marine resource in the islands (Reck 1983, Bustamante et al. 1999). Currently, P. penicillatus makes up over $75 \%$ of the yearly spiny lobster catch, which in recent years has shown signs of decline (Figure 1). In 1998, coinciding with an El Niño event, both total catch and catch per unit effort were the lowest recorded. Subsequent years showed dramatic recovery, producing a record catch in 2000. However, since then, both catch and catch per unit ef- 


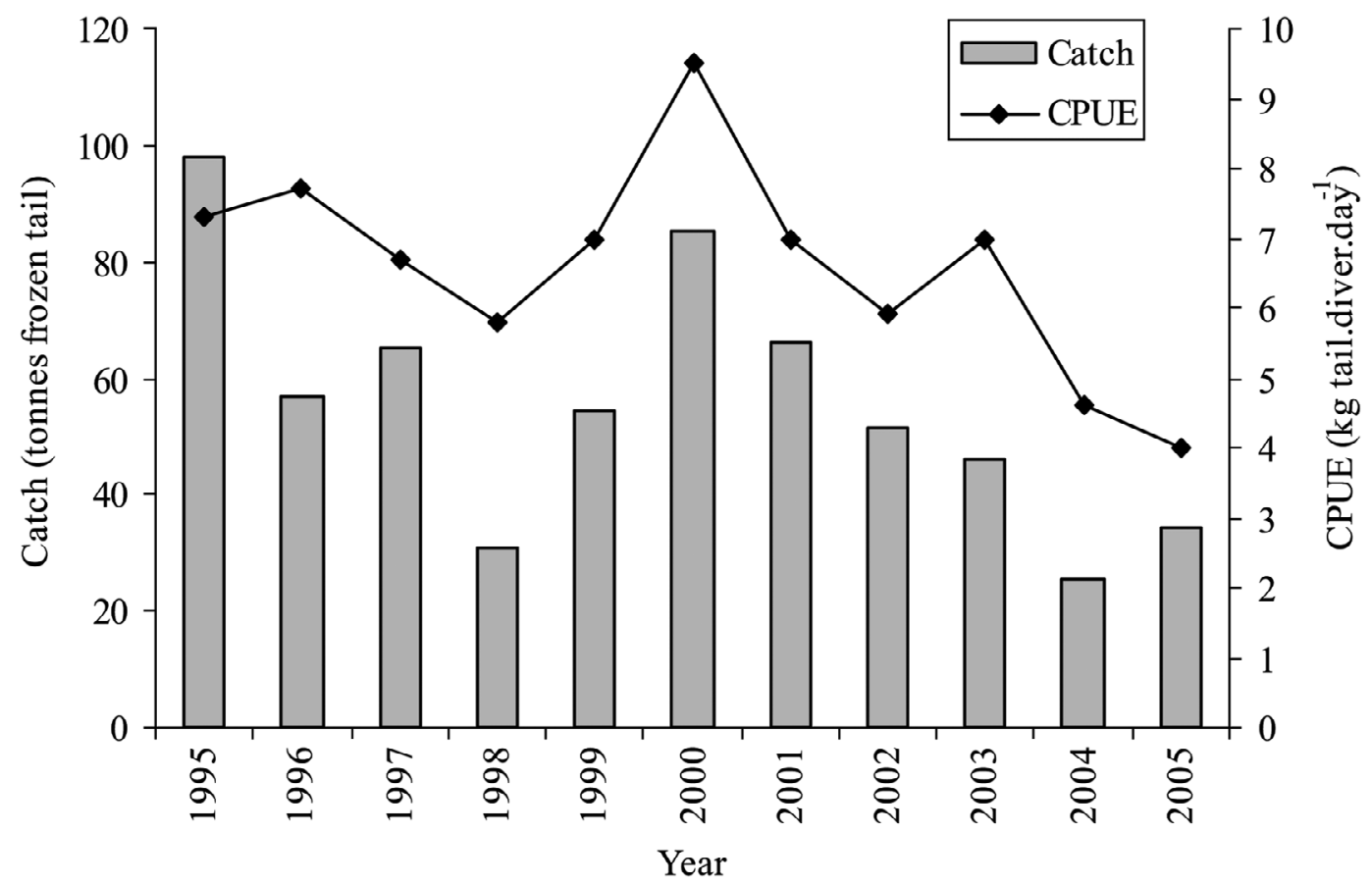

FIGURE 1. Catch (in tonnes of frozen tails) and catch per unit effort (CPUE) (in kilograms of tails per diver day) for spiny lobsters (Panulirus gracilis and Panulirus penicillatus) in fishing seasons 1995-2005. (Source: Charles Darwin Foundation and Galápagos National Park Service databases.)

fort have declined steadily, so that by 2005 , catch per unit effort was $4 \mathrm{~kg} \cdot \operatorname{diver} \cdot$ day $^{-1}$, around $30 \%$ lower than during the El Niño event (Hearn et al. 2006).

The Galápagos Marine Reserve is a multiuse reserve with a coastal zonation scheme that separates certain areas for different uses (tourism and small scale fishing) and sets aside no-take zones that make up $17 \%$ of the coastline (Calvopiña et al. 2006). The Galápagos National Park Service is the administrator of the Galápagos Marine Reserve. However, the management decisions are made by a two-tier participatory system involving several other cooperating agencies and stakeholders, in part based on technical advice provided by the Charles Darwin Foundation.

In this paper we present the results of a survey and mark-recapture program that began in 2000 and is currently still under way, with the aim of providing the users and deci- sion makers of the Galápagos Marine Reserve with information regarding the distribution, abundance, movement, and growth patterns of $P$. penicillatus, thus allowing them to make informed decisions related to catch quotas, closed season length and timing, minimum landing sizes, and spatially segregated management of the fishery.

\section{MATERIALS AND METHODS}

\section{Field Study}

The Galápagos Marine Reserve (Figure 2) is made up of 18 major islands and over 100 islets. Covering an area of $137,000 \mathrm{~km}^{2}$, it includes four distinct biogeographic regions (Edgar et al. 2004): Far North (Darwin and Wolf), North (Pinta, Genovesa, and Marchena), West (Fernandina and western Isabela), and Southeast (the remaining islands).

This study was carried out from Septem- 


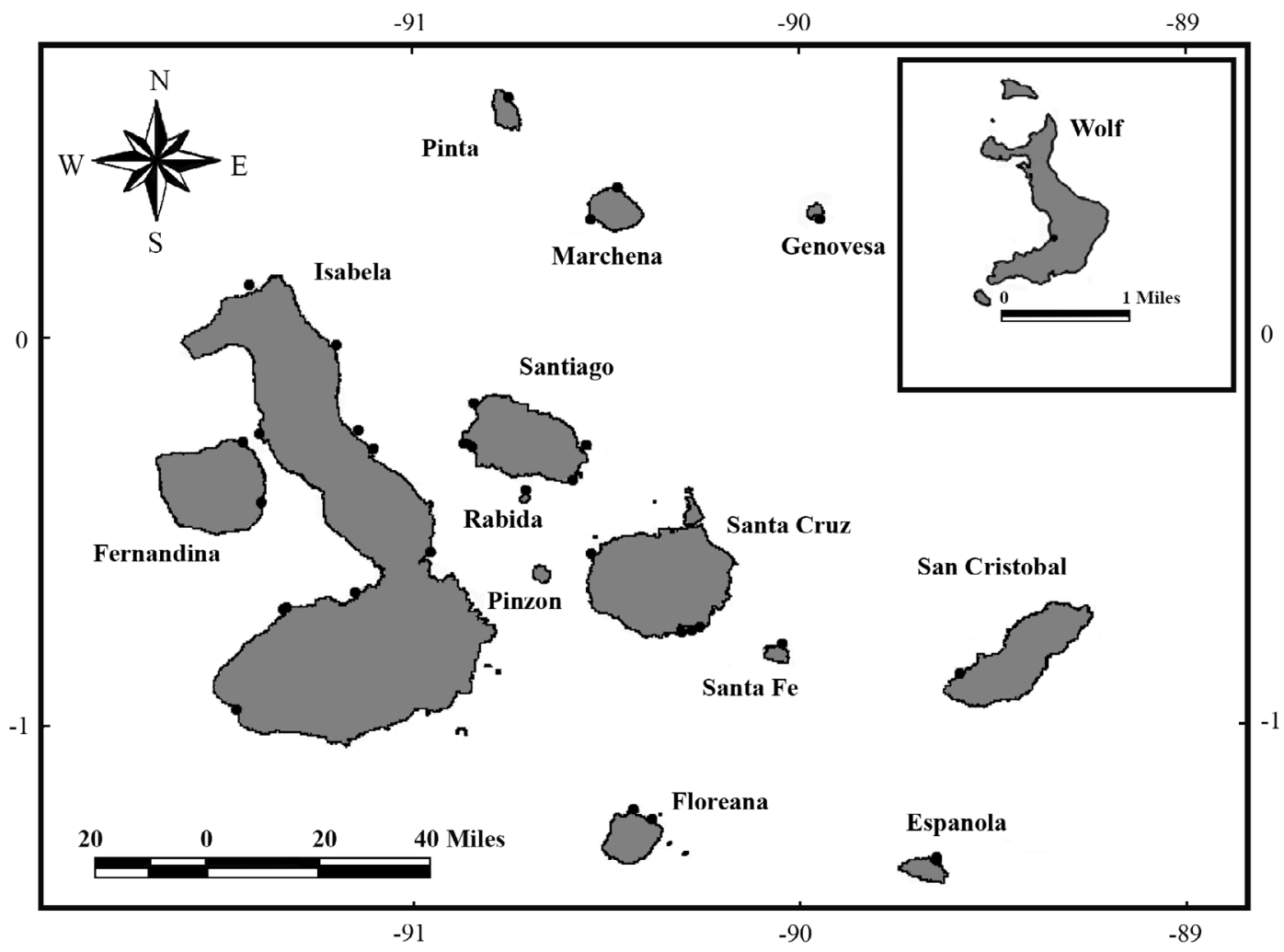

FIGURE 2. The Galápagos archipelago showing spiny lobster sample sites (represented by dark circles). Wolf Island is located to the north of Isabela. $(1$ mile $=1.6 \mathrm{~km}$.)

ber 2000 to December 2004, over 315 diver hours. We sampled 39 coastal sites on 13 different islands across the archipelago (Figure 2). Twenty-minute transects were carried out at night by pairs of divers following the coastline between 0 and $5 \mathrm{~m}$ depth $(60 \%$ of transects), 5 and $10 \mathrm{~m}$ depth (30\% of transects), and 10 and $18 \mathrm{~m}$ depth (10\% of transects). Searches were random within the specified depth zone. The distance between divers was sufficient to avoid duplicate counting of the same animal but close enough for divers to be able to signal to one another using their dive lights in case of emergency. Dives were always carried out on rocky substrates considered to be suitable habitat for $P$. penicillatus, but due to the heterogeneity of the seabed and changing sea conditions, it was not possible to standardize the area surveyed during the dives. All sightings were recorded and, where possible, individuals were captured by hand and brought to the surface at the end of the dive and placed in crates for measuring and tagging.

Standard T-bar tags (Hallprint, Victor Harbor, South Australia) were inserted ventrally into the musculature on the first abdominal segment, at a point halfway between the midline and the right-hand edge. Total length (TL) $\pm 0.5 \mathrm{~cm}$ of all individuals was measured as the distance between the rostrum and the posterior edge of the telson, whereas the carapace length (CL) $\pm 0.1 \mathrm{~cm}$ was measured along the middorsal line from between the postorbital spines to the posterior edge of the carapace. All individuals caught were brought to the surface, where they were sexed, measured, and tagged before being re- 
leased overboard at the surface in the general dive area (generally not more than $100 \mathrm{~m}$ from the capture site).

The local Fishing Sector reported the recapture of tagged individuals, in exchange for a small reward. Some individuals were recaptured during successive visits to the same sites.

\section{Data Analysis}

Relative abundance, or catch per unit effort (CPUE) of lobsters was expressed as the mean number of individuals seen per diver per hour for each island (ind $\cdot \operatorname{diver} \cdot \mathrm{hr}^{-1}$ ):

$$
\mathrm{CPUE}=\frac{N}{\sum\left(T_{1} \times B_{1}+\cdots T_{n} \times B_{n}\right)}
$$

where $N$ is the total number of individuals registered on all dives, $T_{1}$ is the duration of the first dive, $B_{1}$ is the number of divers on the first dive, and $T_{n}$ and $B_{n}$ are the duration of and number of divers on the last dive. The sex ratios for each island were used in a chisquare test to determine whether the overall sex ratio differed from $1: 1$.

Recaptured P. penicillatus provided data on size increment, times at liberty, and general movements. Based on Stewart and Kennelly (2000), individuals of both sexes were grouped by number of days at liberty, using intervals of 60 days. For each 60-day grouping, the proportion of molted lobsters was calculated. The relationship between the proportion of molted lobsters and days at liberty increased from 0 to 1 and was best described by the logistic equation:

$$
y=\frac{1}{1+\exp (b+a x)}
$$

where the probability of molting $\mathrm{y}$ is related to the number of days at liberty $x$; with $a$ and $b$ as the slope and intercept, respectively, of the linear regression of the log-transformed proportion of molted individuals per time interval.

Growth was assumed to follow the von Bertalanffy growth equation (von Bertalanffy 1934):

$$
\mathrm{CL}_{t}=\mathrm{CL}_{\infty}\left(1-e_{0}^{-K\left(t-t_{0}\right)}\right)
$$

where $\mathrm{CL}_{t}$ is length at age $t, \mathrm{CL}_{\infty}$ is the asymptotic length, $K$ is the rate at which $\mathrm{CL}_{\infty}$ is approached, and $t_{0}$ is the age of a lobster at length zero if it had always grown in the manner described by the equation. For the purposes of this study, $t_{0}$ was constrained to zero.

The von Bertalanffy growth function implies that growth decreases linearly with length. Gulland and Holt (1959) showed that it is possible to estimate $\mathrm{CL}_{\infty}$ and $K$ with the relationship:

$$
(\Delta \mathrm{CL} / \Delta t)=a+b \mathrm{CL}
$$

where $\Delta \mathrm{CL}=l_{2}-l_{1}, \Delta t=t_{2}-t_{1}, \mathrm{~L}=l_{1}+$ $(\Delta \mathrm{CL} / 2)$. Thus, $K=-b$ and $\mathrm{CL}_{\infty}=-a / b$.

As hard-shelled crustaceans grow in stepwise fashion, rather than in the smooth pattern depicted by the von Bertalanffy equation, it is necessary to take into account that a molt within a short period of time may give rise to abnormally large estimations of growth rates; at the same time, if no molt has occurred during the time at liberty, growth rate may appear to be zero. For this reason, as in Ulmestrand and Eggert (2001) only individuals that had grown, and been at liberty for over 100 days, were included. Recaptured lobsters were then grouped by sex into $0.5 \mathrm{~cm}$ CL size ranges, and the mean size for each interval $(\overline{C L})$ was calculated. In the same way, mean growth rates $(\Delta \mathrm{CL} / \Delta t)$ were also calculated for each size class.

Jackknife values were obtained as a method for generating estimates of bias and standard errors by resampling the original values of each variable $(\Delta \mathrm{CL} / \Delta t$ and $\overline{C L})$ thus obtaining replicas of size $n-1$, by sequentially eliminating values (Tukey 1958, Levi et al. 1987). Jackknife mean, standard deviation, confidence intervals, and coefficient of variation $(\mathrm{CV})$ were obtained for $K$ and $\mathrm{CL}_{\infty}$ for each sex.

$$
\mathrm{CV}=\frac{\operatorname{StDev}_{\text {Jackknife }(n-1)}}{\operatorname{Mean}_{\text {Jacknnife }(n)}} \times 100
$$

The standard growth index phi prime $\left(\Phi^{\prime}\right)$ (Munro 1982, Pauly and Munro 1984) was used as a measure of overall growth performance and calculated for the sample size $n$ for each sex, based on the relationship be- 
tween $K$ and $\mathrm{CL}_{\infty}$. Phi prime is the constant in the equation $\log K=\Phi^{\prime}-2 * \log \mathrm{CL}_{\infty}$ (Pauly 1979) and has been evaluated for numerous sandy-beach populations of crustaceans and mollusks (Defeo et al. 1992, 2001, McLachlan et al. 1996, Gómez and Defeo 1999) and for fish populations such as Lutjanus campechanus (Leonce-Valencia and Defeo 2005).

An analysis of covariance (ANCOVA) was carried out to determine whether there were significant differences between the growth rates of males and females (Caddy and Defeo $2003)$, with $\Delta \mathrm{CL} / \Delta t$ as the dependent variable, $\overline{C L}$ as the covariate, and sex as the main factor. Assumptions of linear relationship between the dependent variable $(\Delta \mathrm{CL} / \Delta t)$ and covariate $(\overline{C L})$ and the homogeneity of slopes (parallelism test) between $\Delta \mathrm{CL} / \Delta t$ and $\operatorname{Ln}(C L)$ were met.

Natural mortality $(M)$ was estimated using an empirical equation devised by Cruz et al.
(1981), based on 13 species of spiny lobsters, using maximum carapace length $\mathrm{CL}_{\infty}$ (averaged for both sexes), growth coefficient $K$, and the mean annual water temperature, taken as $22.5^{\circ} \mathrm{C}$ (Banks 2002) for the central part of the archipelago, where lobster fishing activity is focused.

$$
\begin{aligned}
\mathrm{M}= & -0.0277-0.0004 * \mathrm{CL}_{\infty}+0.5397 * K \\
& +0.0119 T\left({ }^{\circ} \mathrm{C}\right)
\end{aligned}
$$

\section{RESULTS}

\section{Distribution and Density}

The highest densities of $P$. penicillatus were observed at the northern island of Genovesa (13 individuals per diver hour) and in the far north at Wolf (20 individuals per diver hour) (Figure 3). Both islands are small in comparison with most major islands and are restricted in habitat-the steeply sloping rocky coast-

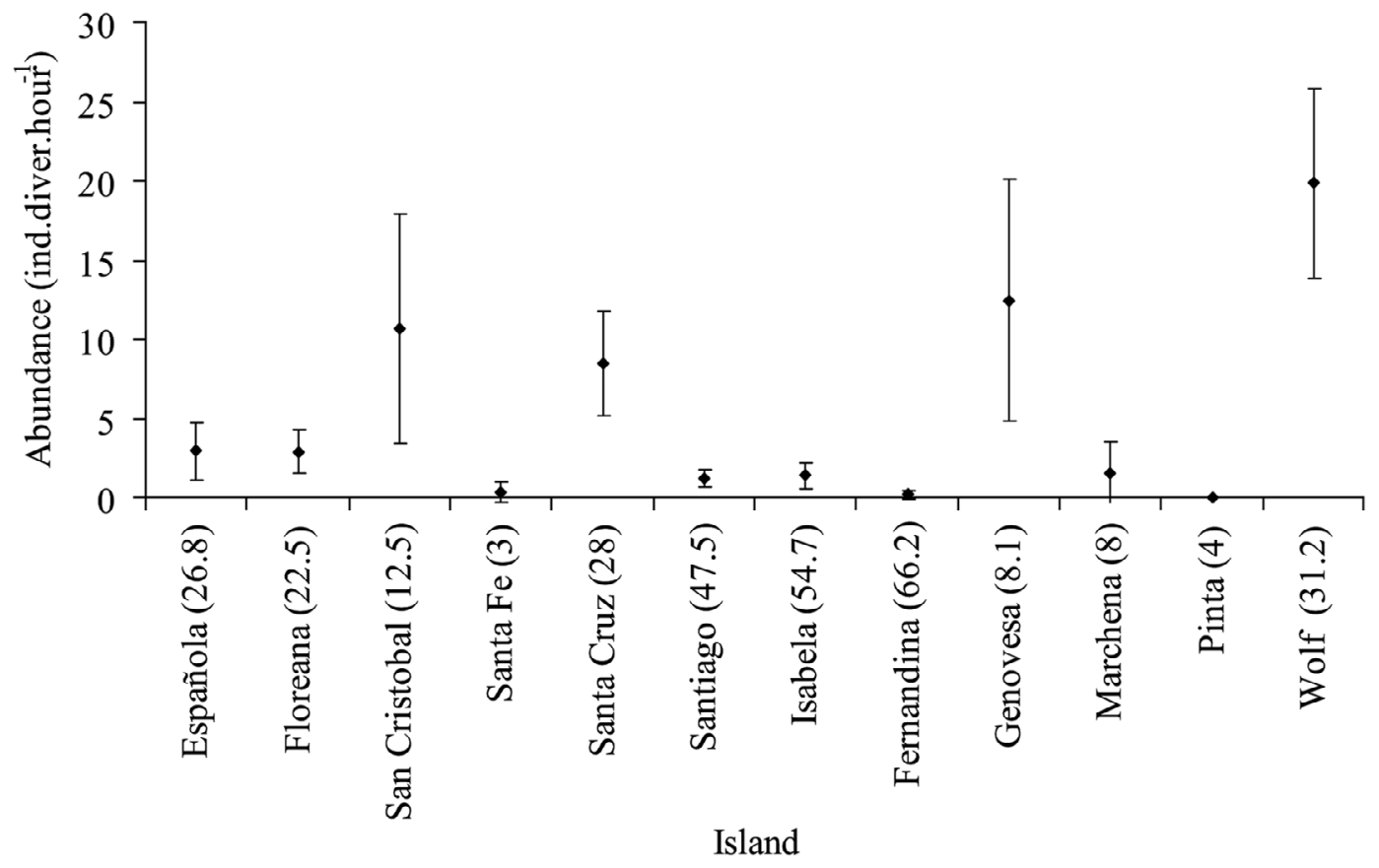

Figure 3. Mean (with $95 \%$ confidence intervals) relative abundance of Panulirus penicillatus observed over 1 hr by diver for each island in the Galápagos archipelago, 2000-2004. Numbers in parentheses refer to sampling effort (diver hours). 


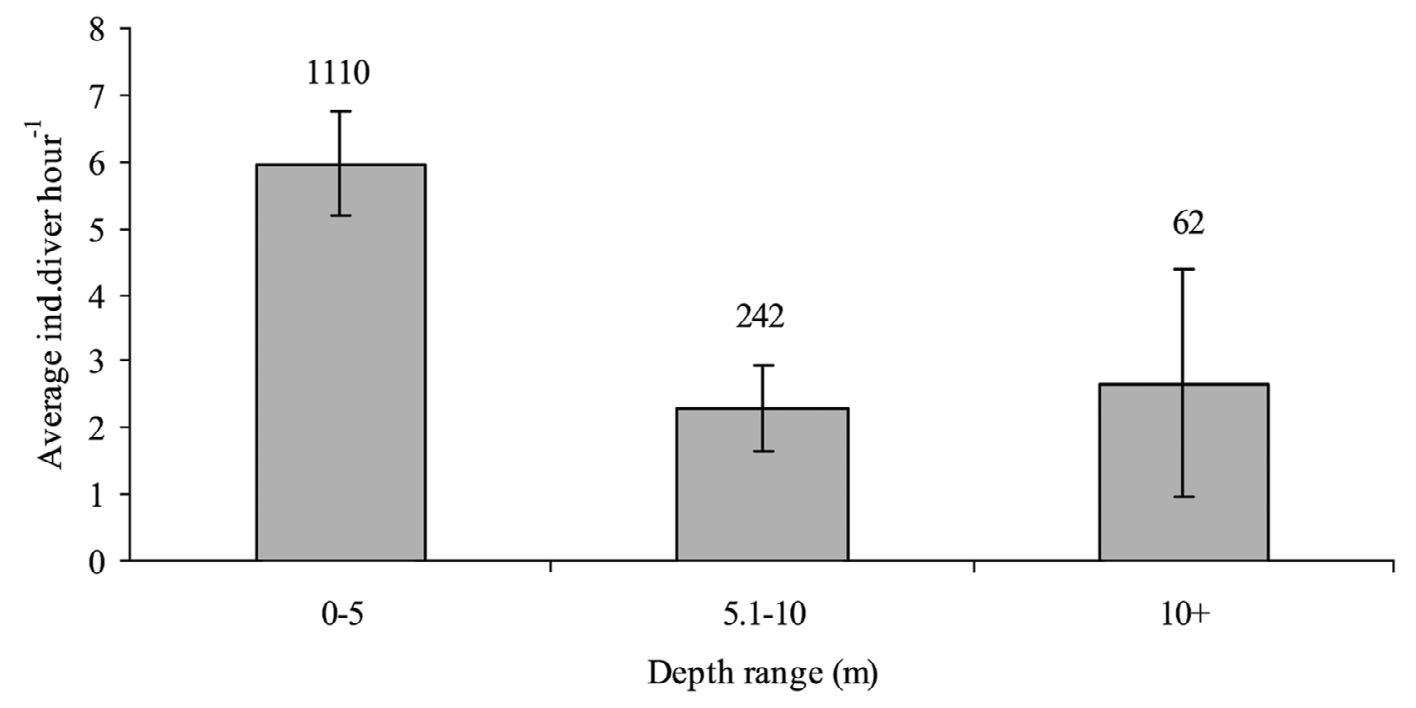

FIgure 4. Mean $( \pm$ SE) density (in number of individuals observed per diver hour) of Panulirus penicillatus per depth range in the Galápagos Marine Reserve (numbers indicate individuals caught).

lines rapidly attain great depths. High densities were also found at Santa Cruz and San Cristóbal Islands (between 8 and 11 individuals per diver hour), with lowest values at the western islands of Isabela and Fernandina ( $<2$ individuals per diver hour).

Highest densities were observed in the first $5 \mathrm{~m}$ of the water column (6 individuals per diver hour), and on average 2-3 individuals per diver hour were observed at greater depths (Figure 4).

\section{Sex Ratio and Size Structure}

A total of 2,918 individuals (1,482 males, 1,417 females, and 15 undetermined) was ob-

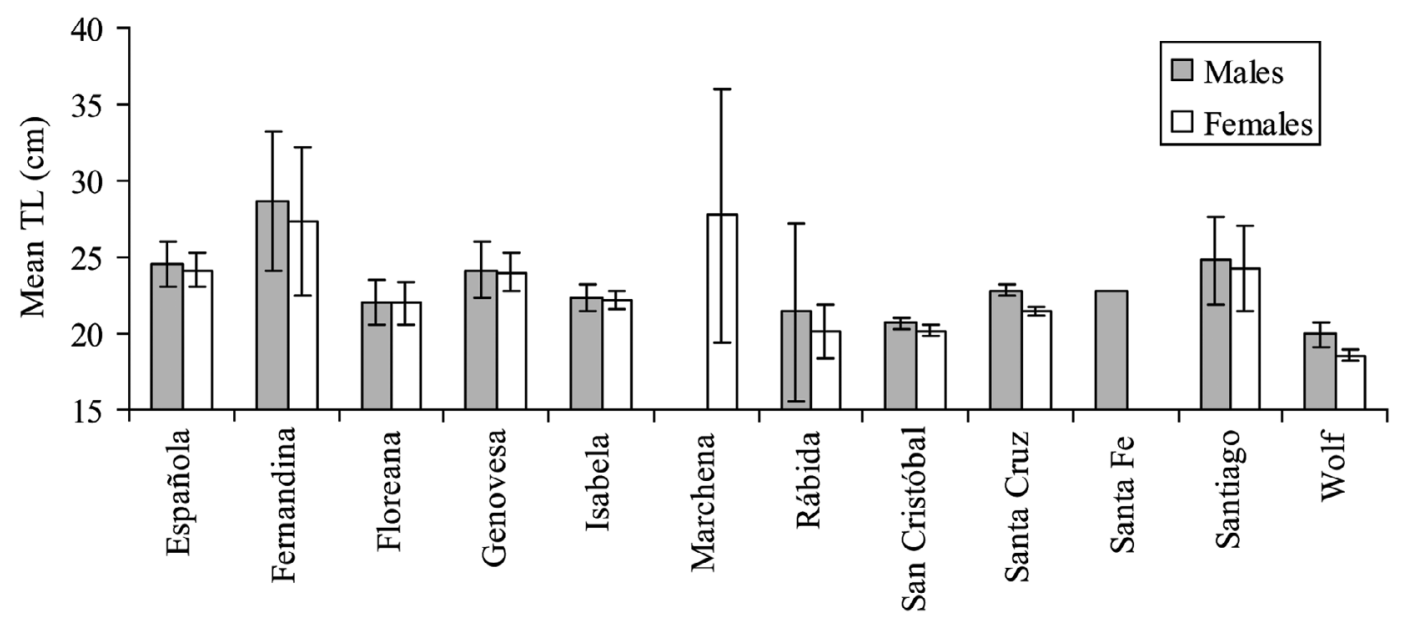

Island

Figure 5. Comparison of mean total length (and 95\% confidence intervals) of Panulirus penicillatus around each island. 
tained during the study period at 12 of the 13 islands (none was found at Pinta). The overall sex ratio did not differ significantly from 1:1 $\left(\chi^{2}=5.62, \mathrm{df}=11, P=.9\right)$. The mean size of individuals ranged from $19.2 \mathrm{~cm}$ TL (at Wolf) to $28.2 \mathrm{~cm}$ TL (at Fernandina), with the largest male found at Wolf $(44.6 \mathrm{~cm})$ and the smallest at Isabela $(6.2 \mathrm{~cm})$. The largest female (found at Santiago) measured 36.6 $\mathrm{cm}$, whereas the smallest (found at Isabela) measured $5.7 \mathrm{~cm}$ TL (Figure 5).

\section{Movements from Tag Returns}

The reported recapture sites of tagged lobsters suggest that lobsters move around within a relatively small area-all 66 individuals recaptured by the research team were found at their sites of release, as were at least 220 of the 422 recaptures by fishers (Table 1). A further 181 reports placed the lobsters within $5 \mathrm{~km}$ of their release site (sometimes at sites adjacent to where they had been released). Only seven individuals were reported as having moved from one island to another. However, due to the distances moved and the depths between islands (in some cases sev-
TABLE 1

Recaptured Tagged Panulirus penicillatus in Relation to Site of Release

\begin{tabular}{lcr}
\hline \hline Recapture Location & Research Team & Fishers \\
\hline Unreported & - & 14 \\
Different island & - & 7 \\
Same site & 66 & 220 \\
Site $<5 \mathrm{~km}$ & - & 181 \\
$\quad$ Total recaptures & 66 & 422 \\
\hline
\end{tabular}

eral thousand meters), these reports must be treated with extreme caution.

Growth

A total of 422 recaptures out of 2,918 $(14.5 \%)$ tagged individuals was obtained. Increase in size was recorded for 71 females and 93 males. The number of days between tagging and recapture (days at liberty) varied from 8 to 1,578 days.

The logistic curve derived from the proportion of molted recaptures in relation to days at liberty is similar to the theoretical curve for yearly molts, assuming no seasonality (Figure 6).

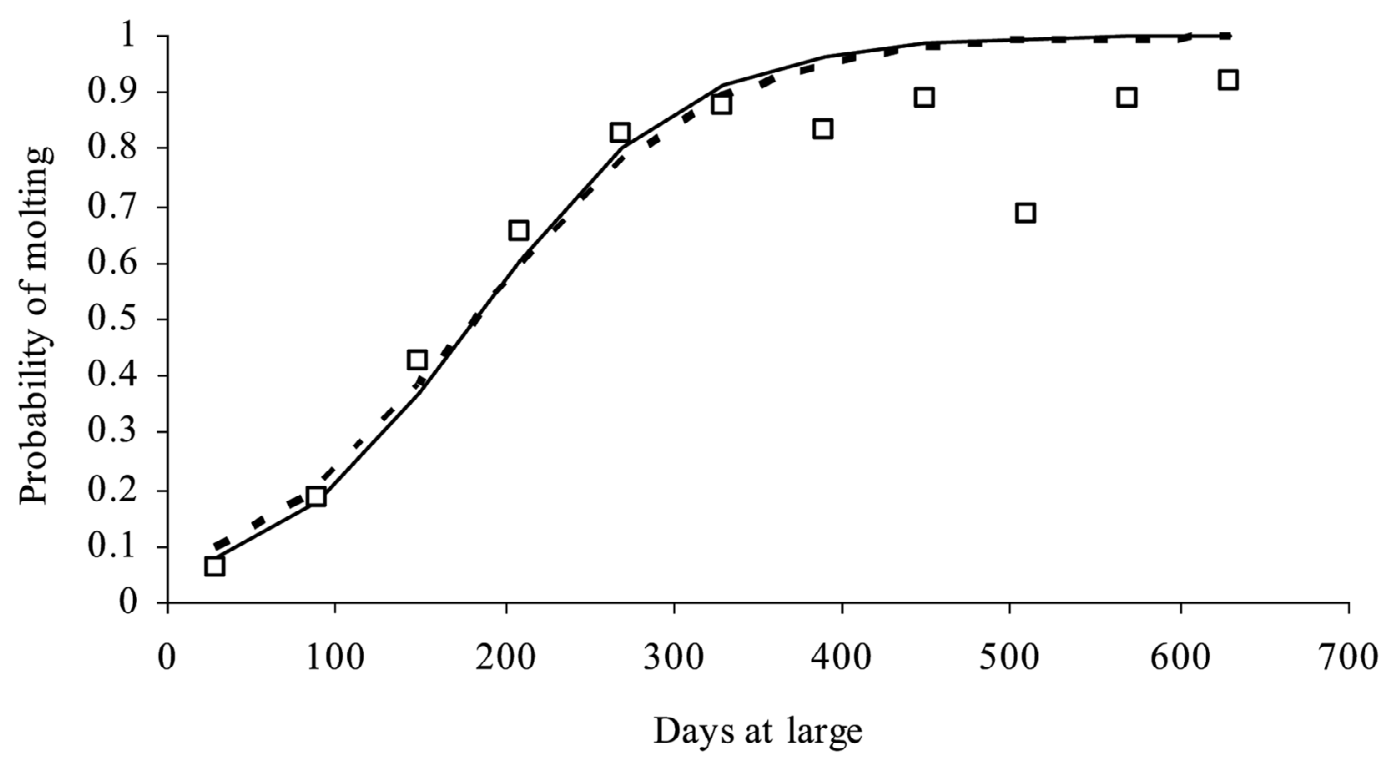

FIGURE 6. Molt probability curve (continuous line) derived from data points on plot, compared with theoretical curve for annual molting (dashed line). 


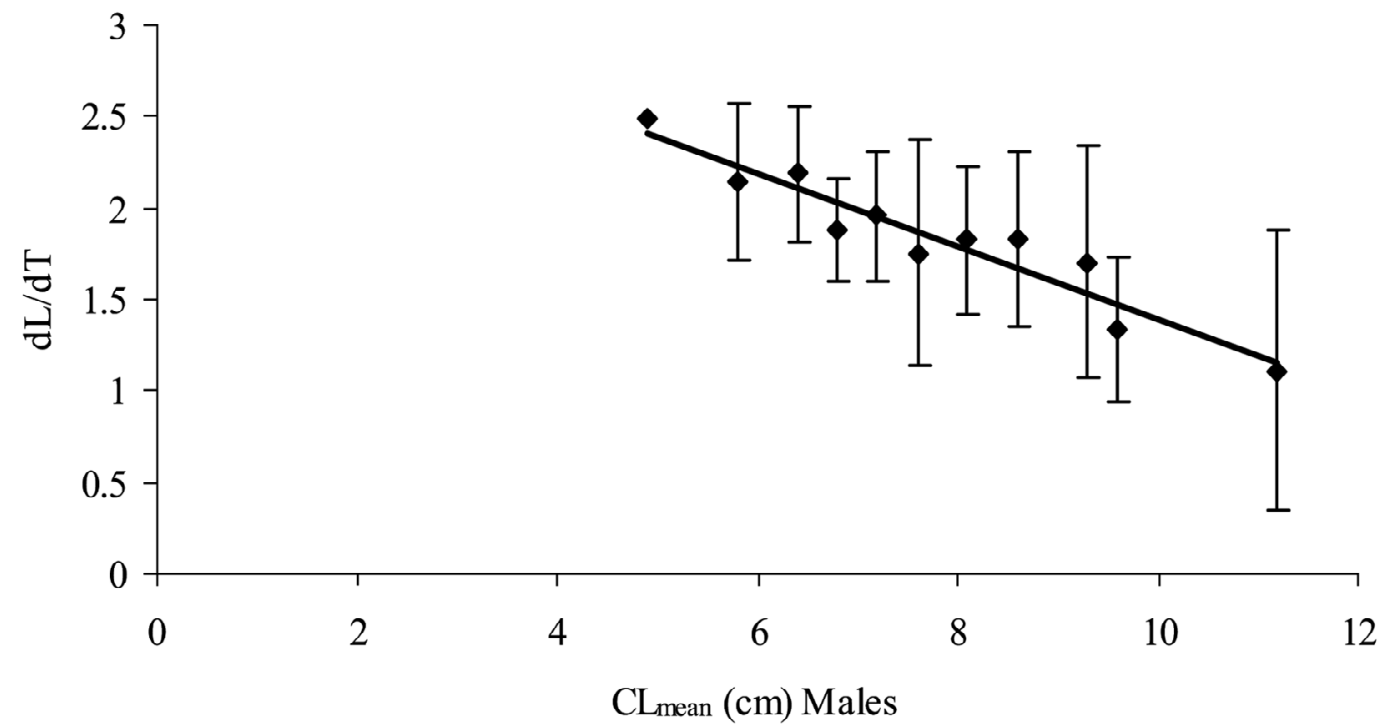

Figure 7. Gulland-Holt plots for mean ( $\pm 95 \%$ confidence intervals) size increment over time for each CL class for male Panulirus penicillatus. (dL/dT, change in length over time.)

Mean values with $95 \%$ confidence inter- for males (Figure 7, Table 2); and $K=$ vals for the growth parameters $\left(K, \mathrm{CL}_{\infty}, 0.264 \pm 0.02, \mathrm{CL}_{\infty}=12.34 \pm 0.40 \mathrm{~cm}\right.$, and and $\Phi^{\prime}$ ) from Gulland-Holt plots were esti- $\Phi^{\prime}=4.99 \pm 0.06$ for females (Figure 8, Tamated to be $K=0.201 \pm 0.004, \mathrm{CL}_{\infty}=$ ble 3 ).

$16.91 \pm 0.183 \mathrm{~cm}$, and $\Phi^{\prime}=4.14 \pm 0.019 \quad$ Growth was found to be significantly more

TABLE 2

Jackknife Pseudovalues and Variation Statistics for Growth Parameters $\left(K, \mathrm{~L}_{\infty}\right.$, and $\left.\Phi^{\prime}\right)$ for Male Panulirus penicillatus

\begin{tabular}{|c|c|c|c|c|c|c|c|}
\hline $\begin{array}{l}\text { Mean CL } \\
(\mathrm{cm})\end{array}$ & $\begin{array}{l}\text { Mean DL/DT } \\
(\mathrm{cm} / \mathrm{yr})^{a}\end{array}$ & $K_{\text {(Jackknife) }}$ & $a$ & $\mathrm{~L}_{\infty \text { (Jackknife) }}$ & $\log \left(\mathrm{L}_{\infty}\right)$ & $\log (K)$ & $\Phi^{\prime}$ \\
\hline 4.9 & 2.5 & 0.19 & 3.3 & 17.37 & 1.24 & -0.72 & 1.35 \\
\hline 5.8 & 2.14 & 0.207 & 3.46 & 16.7 & 1.22 & -0.68 & 1.42 \\
\hline 6.4 & 2.19 & 0.197 & 3.36 & 17.06 & 1.23 & -0.71 & 1.46 \\
\hline 6.8 & 1.88 & 0.206 & 3.45 & 16.76 & 1.22 & -0.69 & 1.43 \\
\hline 7.2 & 1.96 & 0.201 & 3.4 & 16.89 & 1.23 & -0.7 & 1.48 \\
\hline 7.6 & 1.75 & 0.202 & 3.41 & 16.9 & 1.23 & -0.69 & 1.47 \\
\hline 8.1 & 1.83 & 0.201 & 3.4 & 16.9 & 1.23 & -0.7 & 1.48 \\
\hline 8.6 & 1.83 & 0.205 & 3.42 & 16.66 & 1.22 & -0.69 & 1.53 \\
\hline 9.3 & 1.67 & 0.208 & 3.44 & 16.54 & 1.22 & -0.68 & 1.54 \\
\hline 9.6 & 1.34 & 0.192 & 3.34 & 17.41 & 1.24 & -0.72 & 1.57 \\
\hline 11.2 & 1.11 & 0.194 & 3.35 & 17.28 & 1.24 & -0.71 & 1.51 \\
\hline \multicolumn{2}{|c|}{ Mean $_{\text {Jackknife }}$} & 0.2 & & 16.95 & & & 1.48 \\
\hline \multicolumn{2}{|c|}{ Standard Deviation $_{\text {Jackknife }}$} & 0.01 & & 0.3 & & & 0.06 \\
\hline \multicolumn{2}{|c|}{ Standard Error ${ }_{\text {Jacknnife }}$} & 0.002 & & 0.093 & & & 0.019 \\
\hline \multicolumn{2}{|c|}{ Confidence Interval Jackknife $_{\text {S }}$} & 0.004 & & 0.183 & 17.14 & & 0.038 \\
\hline \multicolumn{2}{|c|}{ Coefficient of Variation $_{\text {Jackknife }}(\%)$} & 3.11 & & 1.74 & 16.769 & & 4.14 \\
\hline
\end{tabular}

${ }^{a} \mathrm{DL} / \mathrm{DT}$, change in length over time. 


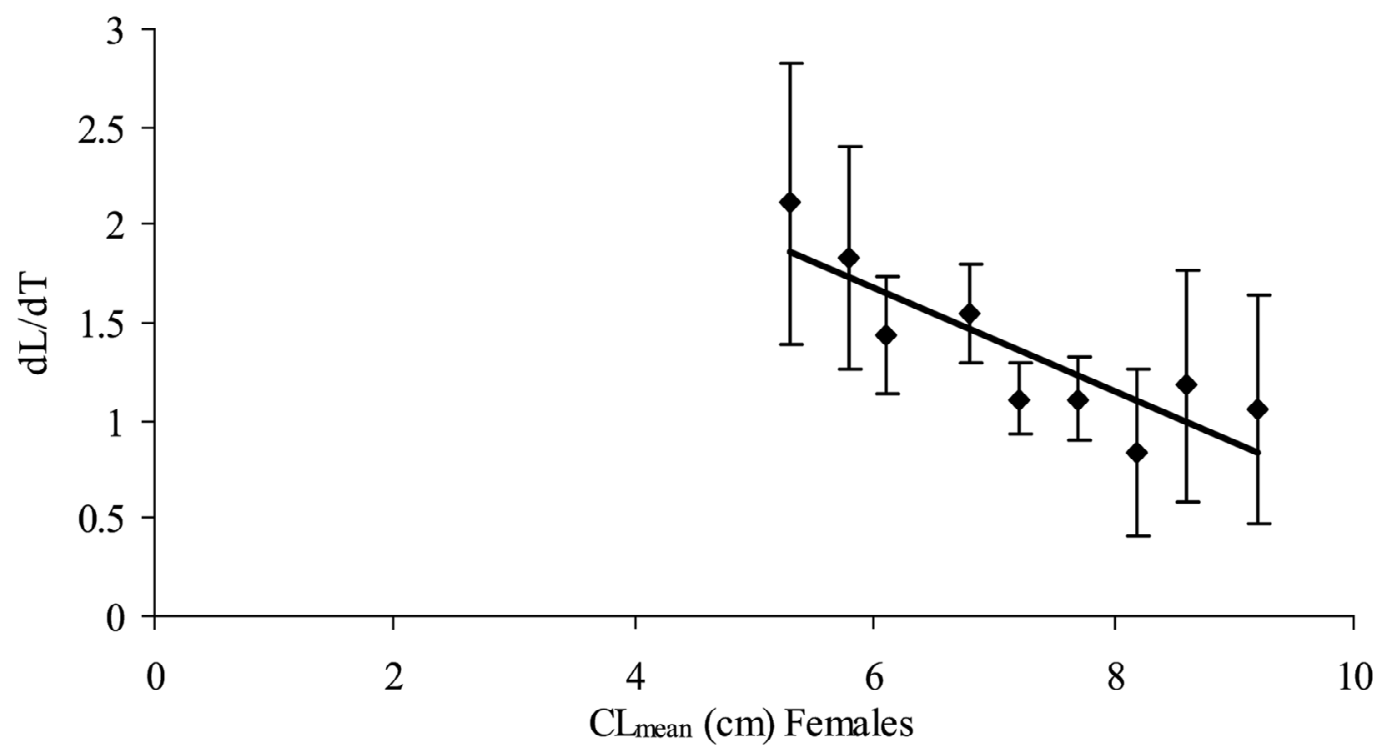

FIGURE 8. Gulland-Holt plots for mean ( $\pm 95 \%$ confidence intervals) size increment over time for each CL class for female Panulirus penicillatus. (dL/dT, change in length over time.)

rapid in males than in females (ANCOVA, $F=56.4, \quad P<.001)$. The correspondent length-at-age curves for both sexes show that the minimum landing size of $26 \mathrm{~cm}$ TL is attained at $4-4.5 \mathrm{yr}$ for males $(9.3 \mathrm{~cm} \mathrm{CL})$ and at $4-5 \mathrm{yr}$ for females $(8.5 \mathrm{~cm} \mathrm{CL}$ ) (Figure 9 ).
Based on Cruz et al.'s (1981) equation for estimating natural mortality on the basis of $\mathrm{CL}_{\infty}, K$, and a mean annual temperature of $22.5^{\circ} \mathrm{C}$, mean values for $M$ were 0.342 for males (0.340-0.344) and 0.378 for females (0.367-0.388).

TABLE 3

Jackknife Pseudovalues and Variation Statistics for Growth Parameters $\left(K, \mathrm{~L}_{\infty}\right.$, and $\left.\Phi^{\prime}\right)$ for Female Panulirus penicillatus

\begin{tabular}{|c|c|c|c|c|c|c|c|}
\hline $\begin{array}{l}\text { Mean CL } \\
(\mathrm{cm})\end{array}$ & $\begin{array}{l}\text { Mean DL/DT } a \\
\quad(\mathrm{~cm} / \mathrm{yr})\end{array}$ & $K_{\text {(Jackknife) }}$ & $a$ & $\mathrm{~L}_{\infty \text { (Jackknife) }}$ & $\log \left(\mathrm{L}_{\infty}\right)$ & $\log (K)$ & $\Phi^{\prime}$ \\
\hline 5.3 & 2.11 & 0.211 & 2.84 & 13.45 & 1.13 & -0.68 & 1.72 \\
\hline 5.8 & 1.83 & 0.251 & 3.15 & 12.55 & 1.10 & -0.6 & 1.95 \\
\hline 6.1 & 1.43 & 0.286 & 3.45 & 12.05 & 1.08 & -0.54 & 1.92 \\
\hline 6.8 & 1.55 & 0.262 & 3.23 & 12.34 & 1.09 & -0.58 & 1.96 \\
\hline 7.2 & 1.11 & 0.264 & 3.3 & 12.48 & 1.10 & -0.58 & 1.97 \\
\hline 7.7 & 1.11 & 0.26 & 3.24 & 12.47 & 1.10 & -0.59 & 1.96 \\
\hline 8.2 & 0.83 & 0.242 & 3.14 & 12.96 & 1.11 & -0.62 & 2.04 \\
\hline 8.6 & 1.18 & 0.289 & 3.41 & 11.81 & 1.07 & -0.54 & 2.01 \\
\hline 9.2 & 1.06 & 0.317 & 3.6 & 11.36 & 1.06 & -0.5 & 2.06 \\
\hline \multicolumn{2}{|c|}{ Mean $_{\text {Jacknnife }}$} & 0.26 & & 12.38 & & & 1.95 \\
\hline \multicolumn{2}{|c|}{ Standard Deviation $_{\text {Jackknife }}$} & 0.03 & & 0.61 & & & 0.1 \\
\hline \multicolumn{2}{|c|}{ Standard Error $_{\text {Jacknnife }}$} & 0.01 & & 0.2 & & & 0.03 \\
\hline \multicolumn{2}{|c|}{ Confidence Interval $_{\text {Jackknife }}$} & 0.02 & & 0.4 & & & 0.06 \\
\hline \multicolumn{2}{|c|}{ Coefficient of Variation Jackknife (\%) } & 11.49 & & 4.94 & & & 4.99 \\
\hline
\end{tabular}

${ }^{a}$ DL/DT, change in length over time. 


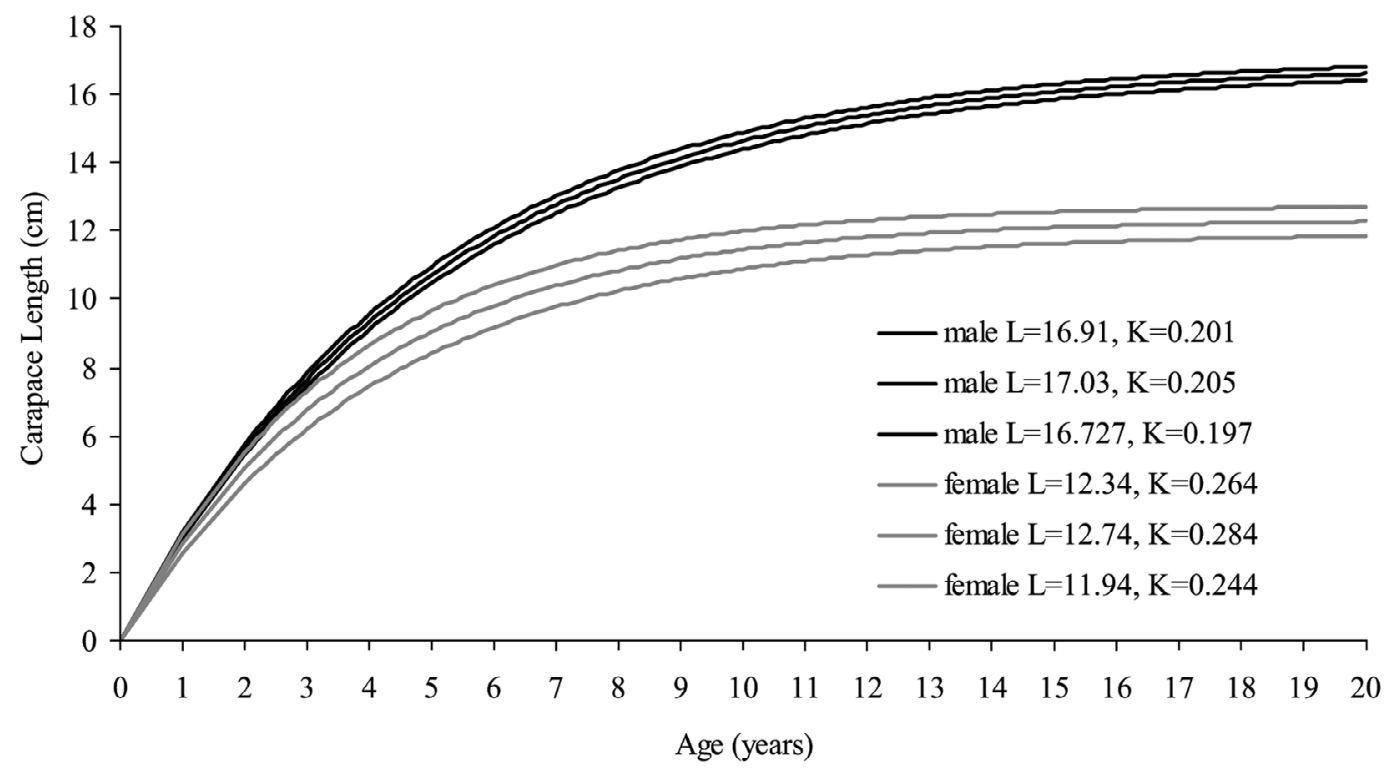

Figure 9. Growth curves for male and female Panulirus penicillatus based on mean parameters for $\mathrm{L}_{\infty}$ and $K$ and maximum and minimum values from confidence intervals.

\section{DISCUSSION}

The relative densities of red spiny lobsters varied throughout the archipelago, with the warmer, northern isles of Wolf and Genovesa displaying the highest densities, and the islands of Santa Cruz and San Cristóbal displaying medium densities. In the western part of the archipelago, relative densities were very low. According to Holthuis (1991), the distribution of this species extends from approximately $30^{\circ} \mathrm{N}$ to $30^{\circ} \mathrm{S}$, throughout the Indian and Pacific Oceans, making it the only transpacific spiny lobster (Briggs 1974). This preference for warm-water habitats may explain the apparent lack of populations in the western islands, which are strongly affected by the cool upwelling Cromwell Current (Edgar et al. 2004).

Panulirus penicillatus is generally described as inhabiting shallow waters from the intertidal to $5 \mathrm{~m}$ in depth, especially in exposed situations on the seaward side of reefs (MacDonald 1971, 1979, Reck 1983, Holthuis 1991). The results of our study show a preference for the depth range 1-5 $\mathrm{m}$, although small numbers of individuals were found down to $18 \mathrm{~m}$. The preferred habitat was almost always exposed rocky reefs, with the exception of Wolf, where (along with Darwin Island) the last remaining coral reefs predominate.

Reck (1983) mentioned collecting specimens at low tide without the use of snorkels or dive gear, and there are anecdotal accounts of catches of 40-50 individuals per hour in the intertidal zone in 1927 according to a national newspaper (quoted in Hearn 2004). The fishery now depends almost entirely on diving to obtain lobsters and has shifted from a daytime activity to a nocturnal fishery over the last $8 \mathrm{yr}$. This is a direct response to considerable declines in the population (lobsters are more vulnerable at night, when they forage) and the almost complete removal of lobsters from the intertidal habitat (Hearn et al. 2006).

The recaptured lobsters showed a high degree of site fidelity, with only seven unconfirmed reports of movements between islands, and 467 of the 474 recaptures with reported locations were either at the release site or at adjacent sites less than $5 \mathrm{~km}$ from the release site. No migrations were observed 
or reported, which is consistent with reports of the same species elsewhere (Plaut and Fishelson 1991). This implies that the Galápagos Marine Reserve is made up of distinct adult populations of $P$. penicillatus, between which mixing is limited or nonexistent, although there may be a mixed larval pool. However, recovery of fishing sites during closed seasons suggests a certain degree of immigration, either horizontally around islands or vertically from greater depths (Hearn 2004).

The sex ratio did not differ significantly from 1:1 in this study, but spiny lobster populations in the Marshall Islands (Ebert and Ford 1986) and in the Red Sea (Plaut and Fishelson 1991) had significantly greater proportions of females. The overall size structure of $P$. penicillatus in the Galápagos has changed dramatically since the 1970 s, from an average size of $30 \mathrm{~cm}$ TL for males and $28 \mathrm{~cm}$ for females to current averages of $21 \mathrm{~cm}$ for both sexes in this study, and $27 \mathrm{~cm}$ and $26 \mathrm{~cm}$ for males and females, respectively, in the fishery, which is regulated by a minimum landing size of $26 \mathrm{~cm}$ (Hearn et al. 2006). Despite this shift in size structure, which is presumably a result of intense fishing pressure, average sizes are larger in the Galápagos than in most other study areas (for example, in the Philippines, where the largest female used in a study of reproduction was $28 \mathrm{~cm}$ [Juinio 1987]). In Dahab (Red Sea), with an average size of $18-20 \mathrm{~cm}$, the $P$. penicillatus population has the smallest average size of any Panulirus species recorded (Plaut and Fishelson 1991). The largest individuals were recorded at Canton Island in the central equatorial Pacific (MacDonald 1979), measuring 20.3 $\mathrm{cm}$ CL, which corresponds to over $50 \mathrm{~cm}$ total length.

The Galápagos population of $P$. penicillatus showed a high degree of variability in its growth rates for both sexes. This is consistent with other populations of the same species (e.g., Juinio 1987, Plaut and Fishelson 1991) and in other lobster species (Morgan 1980, Phillips et al. 1992). The lower $K$ values estimated for $P$. penicillatus in the Red Sea ( $K=0.0497$ and 0.1066 for males and females, respectively) were explained by Plaut and Fishelson (1991) to be the result of the extreme northern location within the distribution range for the species. Juinio (1987) suggested that there were different growth rates for $P$. penicillatus depending on the location of the population, based on the observed smaller sizes at onset of sexual maturity for San Vicente, Cagayan, than for Palau and the Galápagos. This may also have been an effect of exploitation on size structure (Juinio 1987). Plaut and Fishelson (1991) stressed the importance of comparative studies on widely spread organisms, including geographical isolates as well as organisms on the periphery and in the center of the range.

This spatial plasticity may occur not only on a transoceanic scale but within the Galápagos Marine Reserve itself, thus partly explaining the variability displayed. Comprehensive rocky subtidal community surveys show that there are several biogeographic zones, depending on the relative influence of the warm Panama Current from the north, the cool Humboldt Current from the south, and the cold upwelling Cromwell Current from the west, each with a distinct temperature regime and community composition (Edgar et al. 2004). Differential growth rates between the north and west of the archipelago have already been shown to exist for some fish species (Ruttenberg et al. 2005).

Natural mortality for $P$. penicillatus was estimated for Enewetak Atoll, Marshall Islands, as $0.284 / \mathrm{yr}$ for males and $0.244 / \mathrm{yr}$ for females (Ebert and Ford 1986). However, these figures were calculated using Pauly's M equation, which was derived from over 200 species of fish (Pauly 1980) and is likely to overestimate natural mortality in lobsters, whereas the equation developed by Cruz et al. (1981) was based on spiny lobsters and therefore is more suitable for estimating $M$ in other lobster species.

The management of the fishery in the Galápagos Marine Reserve has focused on controlling effort (season length, fleet size) and protecting the reproductive population (minimum landing size and ban on landing ovigerous females). However, it is not clear that the population is self-recruiting or that recruitment is constant. Sporadic recruitment 
pulses have been recorded in the Galápagos Marine Reserve for a sea cucumber (Hearn et al. 2005), and unpublished observations of large numbers of juveniles during the 19971998 El Niño event suggest that this may also be the case for red spiny lobsters in the Galápagos Marine Reserve. Catch quotas based on abundance surveys may be a more appropriate management measure, combined with an overall reduction of fishing effort.

\section{ACKNOWLEDGMENTS}

We thank the dive team at the Marine Department of the Charles Darwin Research Station, the Galápagos National Park Service, and the local Fishing Sector for their collaboration.

\section{Literature Cited}

Banks, S. 2002. Ambiente físico. Pages 22-35 in E. Danulat and G. J. Edgar, eds. Reserva Marina de Galápagos: Linea base de la biodiversidad. Fundación Charles Darwin y Servicio Parque Nacional de Galápagos, Galápagos, Ecuador.

Barr, L. 1968. Some aspects of the life history, ecology and behaviour of the lobsters of the Galápagos Islands. Stanford Oceanographic Expedition 17:254-262.

Briggs, J. C. 1974. Marine zoogeography. McGraw-Hill, New York.

Bustamante, R. H., G. Reck, B. Ruttenberg, and J. Polovina. 1999. Spiny lobster fishing in the Galápagos Islands: Historical trends and current levels of exploitation, management and conservation. Pages 210-222 in B. F. Phillips and J. Kittaka, eds. Spiny lobsters: Fisheries and culture. Fishing News Book, Blackwell Science, Oxford.

Caddy, J. F., and O. Defeo. 2003. Enhancing or restoring the productivity of natural populations of shellfish and other marine invertebrate resources. FAO Fish. Tech. Pap. 448.

Calvopiña, M., R. Visaira, E. Cruz, M. Piu, and J. Dumas. 2006. Implementación de la zonificación consensuada de la Reserva Marina de Galápagos. Pages 105-111 in WWF-USAID, eds. Pasos hacia la susten- tabilidad de la Reserva Marina de Galápagos. Puerto Ayora, Galápagos, Ecuador.

Cruz, R., R. Coyula, and A. T. Ramírez. 1981. Crecimiento y mortalidad de la langosta espinosa (Panulirus argus) en la plataforma suroccidental de Cuba. Rev. Cubana Invest. Pesq. 6 (4): 89-119.

Defeo, O., F. Arregín-Sánchez, and F. Sánchez. 1992. Growth study of yellow clam Mesodesma mactroides: A comparative analysis of three length-based methods. Sci. Mar. 56:53-59.

Defeo, O., J. Gómez, and D. Lercari. 2001. Testing the swash exclusion hypothesis in sandy beach populations: The mole crab Emerita brasilensis in Uruguay. Mar. Ecol. Prog. Ser. 212:159-170.

Ebert, T. A., and R. F. Ford. 1986. Population ecology and fishery potential of the spiny lobster, Panulirus penicillatus, at Enewetak Atoll, Marshall Islands. Bull. Mar. Sci. 38:56-67.

Edgar, G. J., S. Banks, J. M. Fariña, M. Calvopiña, and C. Martínez. 2004. Regional biogeography of shallow reef fish and macro-invertebrate communities in the Galápagos archipelago. J. Biogeogr. 31:118.

George, R. W. 1972. South Pacific islandsrock lobster resources. Available from the South Pacific Islands Fisheries Development Agency, FAO, Rome.

Gómez, J., and O. Defeo. 1999. Life history of the sandhopper Pseudorchestoidea brasilensis (Amphipoda) in sandy beaches with contrasting morphodynamics. Mar. Ecol. Prog. Ser. 182:209-220.

Gulland, J. A., and S. J. Holt. 1959. Estimation of growth parameters for data at unequal time intervals. J. Cons. Perm. Int. Explor. Mer 25 (1): 47-49.

Hearn, A. 2004. Evaluación de las poblaciones de langostas en la Reserva Marina de Galápagos. Informe final 2002-2004. Fundación Charles Darwin y Dirección Parque Nacional Galápagos, Santa Cruz, Galápagos, Ecuador.

Hearn, A., P. Martínez, M. V. Toral-Granda, J. Murillo, and J. Polovina. 2005. Population dynamics of the exploited sea cucumber Isotichopus fuscus in the western 
Galápagos Islands, Ecuador. Fish. Oceanogr. 14:377-385.

Hearn, A., J. C. Murillo, F. Nicolaides, J. Moreno, and H. Reyes. 2006. Evaluación de la pesquería de langosta espinosa (Panulirus penicillatus y $P$. gracilis) en la Reserva Marina de Galápagos 2005. Pages 46-116 in A. Hearn, ed. Evaluación de las pesquerías en la Reserva Marina de Galápagos, Informe compendio 2005. Fundación Charles Darwin, Santa Cruz, Galápagos, Ecuador.

Hickman, C. P., and T. L. Zimmerman. 2000. A field guide to crustaceans of Galápagos. An illustrated guidebook to the common barnacles, shrimps, lobsters and crabs of the Galápagos Islands. Sugar Spring Press, Lexington, Virginia.

Holthuis, L. B. 1991. FAO species catalogue. Vol. 13. Marine lobsters of the world. An annotated and illustrated catalogue of species of interest to fisheries known to date. FAO Fish. Synop. 125 (13).

Juinio, M. A. R. 1987. Some aspects of the reproduction of Panulirus penicillatus (Decapoda: Palinuridae). Bull. Mar. Sci. 41:242-252.

Leonce-Valencia, C., and O. Defeo. 2005. Estimación de la variabilidad de los parámetros de crecimiento de Lutjanus campechanus del Golfo de México. Pages 915-935 in Proceedings, 47th Gulf and Caribbean Fisheries Institute. University of Mérida, Mexico.

Levi, D., M. G. Andreoli, and L. Cannizzaro. 1987. Use of ELEFAN 1 for sampling design. Pages 311-319 in D. Pauly and G. R. Morgan, eds. Length based methods in fisheries research. Proc. ICLARM (Int. Cent. Living Aquat. Resour. Manage.) Conf. 13, Manila.

MacDonald, C. D. 1971. Final report and recommendations to the US Trust Territory Government on the spiny lobster resources of Micronesia. Koror, Palau, western Caroline Isles.

. 1979. Final report to the Western Pacific Regional Fishery Management Council on management aspects of the biology of the spiny lobsters Panulirus marginatus, $P$. penicillatus, $P$. versicolor and
P. longipes femoristriga in Hawaii and the western Pacific. Department of Zoology, University of Hawai'i at Mānoa, Honolulu.

McLachlan, A., J. E. Dugan, O. Defeo, A. D. Ansell, D. M. Hubbard, E. Jaramillo, and P. Penchasjadeh. 1996. Beach clam fisheries. Oceanogr. Mar. Biol. Annu. Rev. 34:163-232.

Morgan, G. R. 1980. Population dynamics of spiny lobsters. Pages 189-217 in J. S. Cobb and B. F. Phillips, eds. The biology and management of lobsters. Vol. 2. Ecology and management. Academic Press, New York.

Munro, J. L. 1982. Estimation of the parameters of the von Bertalanffy growth equation from recapture data at variable time intervals. J. Cons. Int. Explor. Mer 40:199-200.

Pauly, D. 1979. Theory and management of tropical multispecies stocks: A review with emphasis on the Southeast Asian demersal fisheries. ICLARM (Int. Cent. Living Aquat. Resour. Manage.) Stud. Rev. 1.

- 1980. On the interrelationship between natural mortality, growth parameters, and mean environmental temperature in 175 fish stocks. J. Cons. Int. Explor. Mer. 39:175-192.

Pauly, D., and J. L. Munro. 1984. Once more on the comparison of growth in fish and invertebrates. ICLARM (Int. Cent. Living Aquat. Resour. Manage.) Fishbyte, 2 (1).

Phillips, B. F., M. J. Palmer, R. Cruz, and J. T. Trendall. 1992. Estimating growth of the spiny lobsters Panulirus cygnus, $P$. argus, and P. ornatus. Aust. J. Mar. Freshwater Res. 43:1177-1188.

Plaut, I., and L. Fishelson. 1991. Population structure and growth in captivity of the spiny lobster Panulirus penicillatus from Dahab, Gulf of Aqaba, Red Sea. Mar. Biol. (Berl.) 111:467-472.

Reck, G. K. 1983. The coastal fisheries in the Galápagos Islands, Ecuador: Description and consequences for management in the context of marine environmental protection and regional development. Ph.D. diss., Christian-Albrechts-Universität zu Kiel, Kiel, Germany. 
Ruttenberg, B. I., A. J. Haupt, A. I. Chiriboga, and R. R. Warner. 2005. Patterns, causes and consequences of regional ecological variation in a reef fish. Oecologia (Berl.) 145:394-403.

Stewart, J., and S. J. Kennelly. 2000. Growth of the scyllarid lobsters Ibacus peronii and I. chacei. Mar. Biol. (Berl.) 136:921-930.

Tukey, J. W. 1958. Bias and confidence in not-quite large samples (abstract). Ann. Math. Stat. 29:614.
Ulmestrand, M., and H. Eggert. 2001. Growth of Norway lobster Nephrops norvegicus (Linnaeus 1758), in the Skaggerrak, estimated from tagging experiments and length frequency data. Int. Counc. Explor. Sea J. Mar. Sci. 58:1326-1334.

von Bertalanffy, L. 1934. Untersuchungen über die Gesetzlichkeiten des Wachstums 1. Allgemeine Grundlagen der Theorie. Roux Arch. Entwicklungsmech. Org. 131: 613-653. 